\title{
Green Marketing: Marketing Strategies for the Swedish Energy Companies
}

\author{
Usama Awan \\ Department of Management Sciences, COMSATS Institute of Information and Technology \\ Vehari, Pakistan \\ Tel: 0092-333-629-2-629Ｅ-mail: awan.usama@gmail.com
}

Received: September 10, 2011 Accepted: October 05, 2011 DOI:10.5296/ijim.v1i2.1008

\begin{abstract}
Business firms have become aware of the need to protect natural environment and starts practicing the environmental marketing strategies as part of their social responsibility programs. In this paper presents some cases of firms adopting green marketing strategies and exploratory research method is used to analysis and drawn the conclusion. This paper is based on the review of the most relevant literature and empirical studies. The purpose of this paper is to understand the importance of the environmental marketing strategies into the firms operations. This study also reveals that eco-label is differentiate the producers product is environmental friendly or conventional. Key findings of this paper are that corporations cannot afford to stay away from the green market trends and they need to equally participate in the social programs and for this purpose a decision model is developed based on environmental marketing strategies for high green and low green companies which they can adopt as part of their total corporate planning. This environmental model is developed from the study of existing market literature.
\end{abstract}

Keywords: Natural Environment, Marketing Strategies, Green marketing, Eco-Label, Environmental strategic model. 


\section{Introduction}

As the energy market is restructured in Sweden in 1996 since then competition is high among the different energy companies and this competition will create the new opportunities for the companies to introduced environmental based products and introduced new services to attract and keep the customers. Retail competition in energy market will allow the consumer to choose the energy company, some researchers suggest that the consumer will make decision in purchasing the energy, probably depends on environmental products (Wang, 2006).

With the rapid change in the consumer behavior resulting from the green movement towards the sustainability of the environment, the green power products will replace the traditional power products considering the environmental benefits if this phenomenon continues to rise and consumers are willing to pay for the green power then it will create a new market for renewable energy products. Since environmental concern is arising, it may help to emerge green marketing as a successful tool in the energy market (Wiser, 1998). In Sweden Volvo heading towards for development a sustainable environment and sourcing energy from renewable energy, presently Volvo replacing natural gas with renewable biogas for heating the factory. Volvo has made agreement with Vattenfall AB (in Sweden) for supplying energy for its operations, switching to green energy is Volvo part of environmental policy. (Volvo cars, 2011). Sweden is obtaining 45 percent of energy supply from the renewable energy resources. In pursuing of this objective government has established 'The Swedish National Energy Administration' whose responsibility is to planning and monitoring the developments in the energy sector. (Swedish Institute, 2011)

Volvo is planning to start a plug in-Hybrid cars i.e. 'vehicles that use electrical (battery) power and fuel' at mass production in 2010. Sweden's largest power company Vattenfall has made agreement with Volvo cars, company will provide the facility to Volvo cars with larger batteries charged from the power grid (Swedish Institute, 2011).

The green marketing practices offers opportunity to engage people and promote green life styles. From the other side there is also an opportunity to innovate in providing business solutions and achieve profit targets and at the same time build the customer trust on your company. Further describes the green objectives of the business you can change as your competitors are doing 'change the way they see the world' Grant, (2007.p.11). The term 'Green Marketing' although is widely popular these days but yet lacks single accepted definition. In general, green marketing is concerned with all the activities of an organization that may have influence on the environment, both in short- and the long-term. Such activities not only include the development of physical characteristics of products that do not harm the natural environment, but also the processes, promotions, and related claims (Polonsky, 1995, p.181).

\subsection{STRATEGIC QUESTION}

After 1996, when the deregulation of electricity act was promulgated, electricity market in Sweden became open for competition. Increasing environmental concerns in the business 
world have also led electricity companies to focus on environment related issues and implement new activities that reduce or minimize the impact on environment (Wang, 2006). However, the present energy market is dominated by companies producing electricity from conventional resources. In this scenario, green electricity companies are working hard to compete on equal grounds. Hence they face the serious question of "What marketing strategies could be used by the Green Energy Companies to market and to attract consumers towards their services?”

\section{CONCEPTUAL FRAMEWORK}

\subsection{DEFINITION OF GREEN MARKETING}

The concept of society and marketing can be traced in the literature of 1970 s and 1980s (Peattie, 2005) however the notion of social marketing to cover social and ecological responsibilities was introduced by Kotler and Zaltman in 1971 Kotler (2000, p. 6) has defined marketing as 'a societal process by which individuals and groups obtain what they need and want through creating, offering, and freely exchanging products and services value with others'. As the concerns enhanced environment sustainability and green marketing became more popular terms. Grant (2007, p.43) has argued that sustainability internal reforms in the organizations and serves as a 'bridge between business and green' and ensuring to make better 'life of every one now and for generations to come'. The objective of green marketing is to minimize of environmental harm and as well economics benefits.

The term 'Green Marketing' although is widely popular these days but yet lacks single accepted definition (Polonsky, 1995, p.181). In general, green marketing is concerned with all the activities of an organization that may have influence on the environment, both in short and long-term. Such activities not only include the development of physical characteristics of products that do not harm the natural environment, but also the processes, promotions, and related claims. Polonsky (1995, p.199) states that from the organizations' point of view, the impact of green marketing is both internal and external. In the external environment, it affects the threats and opportunities for organizations, whereas in the internal environment it influences the strengths and weaknesses of the organizations.

Green Marketing is defined by Peattie (1995) as 'the holistic management process responsible for identifying, anticipating and satisfying the requirements of customers and society in a profitable and sustainable way'. Furthermore Ottman (2006) explained green marketing satisfies two objectives: improved environmental quality and customer satisfaction. Davis (1993) support that green marketer can develop a communication message which can address the environment problem presenting motivational and relevant attitudes approach in advertising for example communicating that 'you are contributing for the improvement of the society as a whole'.

Further Grant (2007, p.32) has suggested that green marketing objective is to educate and make people willing to go green, because it influences on changing the life style and 
behavior of the people. There are steady movements in public interest and concern about the environmental issues. 'Companies like BASF and DuPont are leading the greening of heavy industry and have had biggest impact on environment'.

Simula et al. 2009 stated that the word 'Green' is widely used today for new technologies and new products which have more sustainable impact on the environment. 'Green', 'Pro-environmental', 'Sustainability', 'Environmentally Friendly' and 'Ecology' are the terms commonly used to describes that the firms' processes and products consume less energy; are recyclable; lessen waste and pollution and preserve natural resource.

\subsection{Why Green Marketing}

Green marketing provides an opportunity to change people behavior like in the case of Facebook, people's holds demonstrate against the decision Facebook announced that 'Massive data center' in Oregan USA will be run on latest energy efficient. (Greenpeace, Feb 19, 2010). Demonstrators were in opinion that facebook should not use Pacific energy supplier (Pacific Power, a utility owned by PacifiCorp). Its primary power-generation fuel is coal. Currently 58\% of its energy generated from coal, and only 21 percent from renewable (Greenpeace organization, Feb 19, 2010). In reply to the Greenpeace movement, Facebook representative said, the geographical location of Prineville and its climate conditions will outweigh the source of the electricity, and energy supplier PacifiCorp is greening up its power sources and will expand wind power to 2,000 megawatts by 2013 (Barnard, 2010).

There are other cases where companies are involved in green marketing to educate the customer for future revenue (Deeran, 2010) in his article analysis that HSBC's is sharing its customers a green life style tips through offering "Green" checking account, a bank providing a bank card with green element recycled paper. Further explained that bank using communication media to make aware the customers that Bank investing in companies that met ethical standards to attract the customers, how bank is take caring for environmental sustainability.

So has the campaign worked? Ms. Rousseau cited that more people are choosing paperless checking (a success point for being green) although this may be correlated with increased usage of the Internet. Perhaps more impressive was the data that showed higher income customers were converting to HSBC at 300\% over previous efforts (Deeran, 2010). Every company is spending a lot in saving the environmental. A famous Coffee chain store Starbucks has introduced an eco friendly disposable cup containing 10\% postconsumer recycled content, to enjoy a tea or coffee and reducing the environmental impacts of serving the coffee (Environmental defense fund, 2006).

According to the report, Starbucks is saving 1.7 million pounds of paper, 3.7 million pounds of solid waste, and 150,000 trees a year if one the average in each store 50 customers to use reusable mugs, star bucks can save 150,000 disposable cups daily. In 2007 there are 13,168 stores; starbucks would have been saved 300,000 from landfills (greenstarbucks, 2007). According to the (Chris, 2010) On this year earth day Dell has set target of planting 150,000 
trees, Dell has signed a partnership and making the donations to the conversation fund if you become a fan on facebook, Dell will plant a tree on your behalf of facebook. One acre of trees removes up to 2.6 tons of carbon dioxide each year.

\subsection{Green Marketing and Corporate Social Responsibility}

The European Commission's defines corporate social responsibility (CSR) as 'a concept whereby companies integrate social and environmental concerns in their business operations and in their interaction with their stakeholders on a voluntary basis Maignan \& Ferrel (2004) define that stakeholders in organization include employees, customers, share holders and suppliers in community includes local residents and special interest groups in regulatory includes municipality and regularity system and the media 'stakeholders'.

Robins (2008) points out that a company must accept its responsibility for its operations and their impact on society and Natural Environment. Companies should work for betterment of society as a whole and more greening the world. Further (Sirsly, 2008) suggested that Corporate Social Responsibility is not always generating the monetary and economic value for the firms, but it helps to promote firm uniqueness efforts towards society. When a third party endorsed its corporate efforts, the reputation of a firm is reinforced in the "eyes of both market and non market stakeholders" Sirsly and Lametrz(2008).

Karna et al. (2003) stated that environmental issues were considered solely the responsibility of the government. Proactive marketing strategies and government support can help in building environmental sustainability. If a firm is introducing a highly differentiated product, it is maximizing the stockholders returns and effectively using environmental strategy. A firm engaged in the cause related marketing because of its long term benefits i.e. Attract and retain consumer for longer period of time. In such type of marketing activity, consumers are emotionally motivate to take part and because they wanted to feel different from other members of society or in their groups Ottman (1993, p.91).

Moving towards green marketing world popular search engine Google has taken initiative to generate environmental friendly energy. According to LaMonic (2008) Google is planning to generate energy (Green energy) by using wave power generator through the wave motion (natural motion of the water) to power the on board data center and has filed a 'Patent' for 'Floating data center' and will cool them with water. She further stated that Google see the future of computing at sea.

Sweden based largest chain store IKEA 'Ingvar Kamprad Elmtaryd Agunnaryd' (Swedish home furnishings retailer) is committed in social programs and has made partnership with the UNICEF for reducing the child labor "The IKEA Way on Preventing Child Labor" helps the children in the developing countries. IKEA has developed a green product "SUNNAN lamp” needs no electricity, SUNNAN is environmentally friendly lamp with rechargeable batteries (solar cells), solar energy would be used to recharge the batteries. IKEA would contribute one SUNNAN solar power lamp to UNICEF against every purchase of one SUNNAN lamp in any of IKEA store around the world (IKEA Foundation, 2011). 
According to Dell Senior Giving Manager, Dell has started youth Connect program to educate children in Mathematics, Science, Literacy and technology. Dell climate exchange program 'The Energy and Resource Institute' (TERI) making awareness of 10 Indian states students and providing necessary information technological support for research on environmental issues (Bauer, 2010).

Being a trustworthy company Dell has initiated efforts to create awareness among the students about the environments, In South Africa, Vele secondary high school, where company supporting a computer class room in an environmentally responsible green school, where rain water is recycles harvested from roofs and paved areas. Dell also supporting community centers in Brazil, Mexico(Bauer, 2010).According to (Hanson, 2003) Survey carried by KPMG from world largest companies in 16 industrialized countries noted that half of employee wanted to work for those companies who are working in corporate social responsibility (CSR)

\section{GREen MARKET SEgMENTATION}

Fuller (1999, p.334 and Baumann \& Rex, 2007, P.569) in his book of Sustainable Marketing the present the profile of Green Consumer as follows:-

\subsection{True Blue Greens (12 Percent)}

- Participate in wide range of pro-environmental activities.

- Have high socio economic status i.e (education, income and occupational level)

- Monetary Contribute for the environmental issues and interaction with politicians.

- Committed and hard core environmentalist \& avoid products that are not made by environmentally friendly companies.

\subsection{Green Back Greens (6 Percent)}

- Ready to pay a premium for environmental friendly products.

- Generally younger and prefer to buy and give green and don't like to change life style.

- Have high socio economic status i.e (education, income and occupational level)

\subsection{Sprouts (37 Percent)}

- This group can serve as 'feeder' to the Green back and True Blue Segment. They do not prefer to buy green products but able to buy that product.

- Have high socio economic status i.e (education, income and occupational level)

- They are in middle of road in social and political status.

- Rank well in pro environment behavior.

\subsection{Grousers (13 Percent)}

- This group is not involved in pro environmental behaviors and issues in general. 
- They have a consistently socio economic status i.e (education, income and occupational level)

- They develop own logic and have reason for not participating for the environmental activities.

\subsection{Basic Browns (29 Percent)}

- This group avoid themselves to be involved in environmental problems.

- Show a low interest in economic status i.e. (education, income and occupational level)

- Do not blame others for environmental problems and not makes effort to save environment.

- Focus on their immediate $\&$ day to day activities.

\section{Green Marketing Strategies}

Ottman (2006) further suggests that all marketing activities must convince the consumers through identifying the basic product features. He suggested the following Strategies

\subsection{Consumer Value Positioning}

A firm should focus in designing a product, which is differentiated from and performs better than the alternatives.

\subsection{Calibration of Consumer knowledge}

In designing marketing communication, a firm should always present product unique features, environmental benefits and solutions that matched with the Customer norms and values.

\subsection{Credibility of Product Claim}

A firm should build confidence in the consumers' minds by presenting or communicate benefits of the product "that are specific and meaningful and qualified for the consumers”.

Davis (1993) explained that consumer wanted to know about the particular and specific information about the product or service which they about to buy are environmentally friendly. Through advertisements on radio, on billboards \& in print media, are making aware the consumers about the environmental issues by the green companies along with price that has substantial effect on consumers to choose a new electric supplier (Glaser, 2009). Consumer's decisions influence by the media, as a stakeholder, the role of media cannot be ignored; it is the only source through which a consumer received much of environmental related information Ottman (1993, p.91).

Vaccaro (2009) has presented two main strategies for the companies in responding to their external environment as 'proactive strategies' (First Mover) and 'reactive strategies'. In reactive strategy, organization starts making adjustments in its operations when threats and/or opportunities are seen, whereas in proactive strategy, firm responds to the external 
environment before changes occurred The same approach is also presented by McDaniel et al.1993) called first mover ‘Defensive’ and reactive ‘Assertive’ approach.

In 'Defensive or reactive approach' a firm meet minimum standards set by the government in order to avoid tax penalties and reacting to competitors and sometimes to avoid boycotts from consumers not to avoiding environmental regulations. Whereas in using the 'Assertive approach' a company has opportunity for creating competitive advantage. This approach is also known as 'First mover'. It is an image creates strategy for the firms to do more than it is required (McDaniel, 1993). Adopting a proactive approach, a firm can find the best available cost effective solutions, and built long term relations with their customers and create a good will image in Public. Ottman (1993 P.60)

Miles and Covin (2000) define two interdependent philosophies the 'compliance model' typically defensive and 'strategic model' firms adopt simply proactive approach companies tend to create competitive advantage(Porter and van der Linde, 1995) socially responsibility is a source of innovations (Sheth and Parvatiyar,1995) achieve through proactive marketing strategies examine 'new market orientation'.

Companies make their offerings competitive through price/quality or prestige/image strategies from their competitors but eco friendliness and social responsibility make companies more profitable (Darling et al. 2009). Early mover companies have enhanced their image as environmental friendly. The Municipality owned electricity companies of Stockholm and Goteborg set example as early movers. In 1999 Swedish state-owned railway company SJ bought 'Bra Miljöval' labeled electricity (Kaberger, 2003). Other studies by Karna et al. (2003) suggested that companies can create competitive advantage if they use innovations related to environmental sustainability rather than simply comply with the government regulations. Adopting a proactive approach, a firm can find the best available cost effective solutions, and built long term relations with their customers and create a good will image in Public. Ottman (1993 P.60)

Previous studies and research have presented the similar conclusion on the green marketing (D’Souza and Taghian, 2010; Diamantopoulos et al.2003; Straughan et al.2003; Peattie, 2001) have discussed that Green marketing changing consumers' behavior and provide tools and techniques to guide organization to achieve social objective and educate customers about the adverse effect of environment and help companies to be innovate in their process and product technologies.

Procter \& Gamble is promoting environmental friendly products and also has launched future friendly media campaign to educate the consumers to use "tide cold water" for laundry instead of hot water, since much of energy consumed in heating the water (environmentalleader, 2010).

Many firms have taken proactive approach in targeting the future buyer (Green Buyers) that is. young children teens, college students are potential green consumers and firms reaching through this segment by educating the youth adopting different programs like Discovery, network earth cable news network CNN's (Caption Planet) For example, Dow using live rock 
Band McDonalds start publishing educational magazine 'Wecology' Ottman (1993, p.81). Peattie et al. (2005) further suggested that companies should put more focus on cost of the operations 'instead of price' in their marketing communications.

\section{Green Power \& Marketing}

Energy generated from natural and renewable resources such as sunlight, wind, biomass, tides and geothermal heat, is called 'renewable energy'. The renewable energy market is still growing and governments are making policies for this sector and companies are putting more efforts to commercialize these resources due to the rapid changing in climate, high oil prices and pollution (Shi, 2010).

According to Bird et al. (2002) green power products are generally 100\% renewable energy offerings and are produced from either a mix of several renewable resources or a single resource such as hydro or wind. Small numbers of these products are selling at the cost of conventional electricity while others have $10-30 \%$ premium price than conventional electricity. Kreidler \& Joseph (2009) define a green product as which is totally or partially created from recyclable or renewable materials.

Energy companies are providing the power as a product to the customers at some accepted cost with showing product or service differentiations against competitors in the market (wiser, 1998).After starting the retail competition in the power market, many companies started to target niche market by differentiation products and services. In current competitive market, only those companies will be survived whose product and services are different from other, success of such companies less or more will depend on their customer service based approach (wiser,1998). The cost and knowledge of a green power product is an important factor in making decision of changing the alternate electric supplier. Switching cost and cost of searching a new energy supplier however is important; however switching behavior is prevailing among the Swedish electricity consumers. The most note factor why a consumer will switch to another electric supplier is availability of different pricing contract with electricity suppliers (Ek and So“derholm 2008).

Stockholm Energi, the electric utility in Stockholm, Sweden in 1994 offered customers a bundle power package to pay $\$ 35$ per year to choose among nuclear, hydro or locally-cogenerated power. In Sweden, $45 \%$ of existing electricity resources is hydro $50 \%$ is nuclear, and most of the remainder is combined heat and power (Hold, 1997).

\subsection{ECO-LABEL}

Ecolabell differentiates the products whether these products are environmentally friendly or not. Since 1991, more than 1000 Eco label license have been awarded till Jan 2010 (European commission environment, 2011).In 1996, Swedish Society for Nature Conservation (SSNC) introduced ecolabeling on electricity with label 'Bra Miljöval', which is translated in English as 'Good Environmental Choice'. In Sweden, ecolabeling was started back in 1988 and presently 12 different products are covered under this scheme (Ecolabelling green consumerism, 2011). 
According to Benedetto (1995) Germany has started "Blue Angel” label to be applies on the package of those products that reduces noise pollution, lessoning effect to ozone layer or minimize the effect of mercury pollution. Canada has taken initiative and introduced label for recycle motor oil, water based paints, and product made from recycled plastics and recycled office and copy papers. The practical importance of Ecolabell is to encourage consumer to purchase a product which is less harmful for the environment form those products in same product category. Consumers willingness to purchase environmentally product directed his self interest to have a greater trust on the manufacturer and producer (Luukkanen, 2003).

A consumer will buy such labelled product for which he has developed trust in the label and compare the information with competitors and other available resources. A trusted label product will increase the market share of the product(Grankvist et al.2004; Thøgersen,2000) also suggested that within the industry the Ecolabell can undermine the competitive position of actual environmental leader, on the other side the producers are willing to compete on environmental grounds (Luukkanen, 2003).

\subsection{MARKETING MIX}

The first concept of 4Ps (product, price, place and promotion) was presented by Rasmussen, A. later further enhanced by Kotler, P. Marketing Mix concept was based on the some defined set of models, after 1960s when new 4Ps concept was introduced; it converted into a research field and established a theoretical ground (Håkansson and Waluszewsk, 2005).

Marketing mix is develop for successful marketing penetration of a product to fit according to the customer's needs and wants and competitiveness position can be achieved through offering a successful component mix. Marketers made decision for their offering on the basis of the future developments in the market; a firm has different objective and goals, and develops appropriate strategy for marketing mix over a period of time (Darling et al. 2009)

\subsubsection{Product}

A product must hold distinguished position in buying and selling process. The attributes of a product some time carrying opportunities, restriction and tension, product will always exposed and suggest some benefits for the consumer (Håkansson et al. 2005). Renewable power products are generally positioned as a bundle of packaging is offered by the electric supplier (Wiser, 1998) renewable power products can successful in market as they positioned themselves supporting environmental issues.

\subsubsection{Price}

In the marketing mix model, Price is the only element that can create a perfect mix between the revenue and profit, rest other elements create costs (Håkansson et al.2005).

Incentives by the Govt. in renewable energy and cheap prices by the electricity producers create demand for the green power. if electric supplier given value to price, he can capture a large share of green power in residential area (Glaser, 2009). 
Charter \& Polonsky (1999) present a case of Electricity retailer of Massachusetts Electric Company offer a green option program for power consumer by offering three different options Price, Green and other option to donate to charitable.

(Charter et al.1999) Further explain that power companies needs to link their marketing strategy in lines to make power consumer aware about the sustainable environment. Power consumers should provide choices in terms of price and renewable energy content, i.e. premium price for electricity that has $75 \%$ renewable energy content and pay fewer prices that have $50 \%$ to $25 \%$ renewable content. Wüstenhagen (1998) suggested in his article penetration pricing strategy have high application in the green electricity. In other case if a company adopt skimming pricing strategy and cut prices in the later, company can be benefit because consumers willingness to contribute their efforts to save the environment and later it attracts new customers from other segments.

\subsubsection{Place}

Place is not a cost generator factor, it has many features that can create revenue and certain outcome. This element of the marketing mix is dealt 'how-to-handle-distanc' (Håkansson, 2005).

\subsubsection{Promotion}

According to (Håkansson et al., 2005) this element of marketing mix creates interaction with the consumers and makes the product position distinguished in the market. In 1990s Swedish power company Vattenfall started a large advertisement campaigns in Finland of wind energy which force finish power companies to invest in renewable power resources.

\subsubsection{Strategies}

Companies make their offerings competitive through price/quality or prestige/image strategies from their competitors but eco friendliness and social responsibility make companies more profitable (Darling et al. 2009). Studied the framework of implication of the greening strategy and discuss the structure and process of organization how they can integrate it into their objectives Banerjee,1999; Wehrmeyer, 1999; Pujari and Wright, 1996) Early mover companies have enhanced their image as environmental friendly. The Municipality owned electricity companies of Stockholm and Goteborg set example as early movers. In 1999 Swedish state-owned railway company SJ bought 'Bra Miljöval' labeled electricity (Kåberger, 2003).

Vaccaro (2009) state that green marketing can be considered as a subset of Corporate Social Responsibility (CSR) strategies. Vaccaro, p.316, 2009) created a classification of four groups of CSR theories

- Instrumental theories

- Political theories

- Integrative theories

- Ethical theories. 
In 'Instrumental theories' a firm achieves competitive advantage and helps social causes such as philanthropic investments and cause marketing activities. 'Political theories' are related to the use of business power and government regulations have been applied to environmental marketing. Integrative theories focus on stakeholders management, related to social norms, green marketing and to the common good. Finally, ethical theories focus on doing the right thing for the common good.

Vaccaro (2009) further explained that the 'disruptive innovation' is helpful in achieving social objectives and 'creates competitive advantage for companies in telecommunication and particularly in energy production and many others'. Karna et al. (2003) suggested that companies can create competitive advantage if they use innovations related to environmental sustainability rather than simply comply with the government regulations.

According to Baumann and Rex (2007), The Demand measurement discovers the size of the green market and divides the total markets into groups of consumers with different needs and characteristics. In positioning the product the Eco label should be taken into the consideration for green products.

\section{CONCEPTUAL MODEL ADOPTED BY AUTHOR FOR STRATEGIC QUESTION}

From the theories discussed in the literature review, authors have adopted this model to see that what strategies are available for the actual green companies. Authors modified and adopted this model for those companies who see themselves as a least green and those who see themselves as a highest green. This model will help to choose the right strategy for their right segmentation and market. The companies who are lowest in green but wanted to increase the market share can follow the following strategies and those companies who are most green in his operation can choose the strategies. In literature it has been discussed that business or social oriented firms from all over the world are integrating environmentally friendliness in their product and production process.

The company perceiveness is important in the eyes of the customers, In some companies the actual greenness is low and some companies are actual greens, at this point companies needs carefully to evaluate their market strategy. Presently the environment concern has gain popularity in all the fields of life and consumers are becoming very cautious about the worse effect of the product and production process of firms. In this scenario business firms needs to address these issues through strategic management approach.

In the figure.1, the term 'environmentally improved products' the product is made by recycled material. And the term 'Re-invented product' the product is made by the use of some new product or process technology.

According to Wal-Mart 2011 annual report presented the fact that in 2010 company sold more of the products were environmentally improved products, for example More than 80 percent of the paper notebooks and 100 percent of copy paper items sold in Wal-Mart U.S. were derived from certified responsibly managed forests.(Wal-Mart globally social responsibility report,2011) The use of Ecolabell guide the customers that the product is environmentally friendly and directs consumers to buy this products. 


\begin{tabular}{|c|c|c|}
\hline & $\begin{array}{l}\text { Environmentally } \\
\text { Improved Products }\end{array}$ & $\begin{array}{l}\text { Environmentally Re-invented } \\
\text { Products }\end{array}$ \\
\hline $\begin{array}{c}\text { New } \\
\text { Markets }\end{array}$ & $\begin{array}{l}\text { Pricing Strategies } \\
\text { Social Responsible } \\
\text { Communication } \\
\text { Product Improvements }\end{array}$ & $\begin{array}{l}\text { Product Development Strategy } \\
\text { Maintained actual Position }\end{array}$ \\
\hline \multirow[t]{3}{*}{$\begin{array}{l}\text { Current } \\
\text { Markets }\end{array}$} & $\begin{array}{l}\text { Market Growth Focused } \\
\text { Focused on Process } \\
\text { technologies } \\
\text { Sells product benefits } \\
\text { Re-Positioning as } \\
\text { Innovators }\end{array}$ & $\begin{array}{c}\text { Support Green Initiatives } \\
\text { Focused on Eco-label as } \\
\text { positioning } \\
\text { Innovation Marketing } \\
\text { Service Focused }\end{array}$ \\
\hline & Low Green & High Green \\
\hline & \multicolumn{2}{|c|}{ Position of Companies } \\
\hline
\end{tabular}

Fig.1 Strategic Decision Marketing Model Modified By Authors

Source. Fuller (1999, p.105) \& Simula, Lehtimark \& Salo (2009, p.349).

\section{Discussions}

As environment conditions changed has forced the company to adopt some green practices into their business and many companies have become prosper and gained competitive advantage by adopting a number of publically accepted business practices. According to this study and the literature has been reviewed firms required critical thinking to survive in the market. Apart from the other marketing strategies this model helps to differentiate the company is either low green or high green. The true green companies has opportunity to take advantage by adopting proactive strategies to pursue consumers through educating about the adverse effect that conventional electricity has over environment and promote itself as a socially responsible. Environmental modified Strategic model presents different strategies, which companies can adopt while entering in an existing or in new market. If the company is not actually green, they can see what different strategies are available for them when they want to enter into a new or existing market.

The analysis shows that companies can use ecolabeling of their product in communication; 


\section{MInstitute Macrothink $_{\text {Int }}$}

International Journal of Industrial Marketing

ISSN 2162-3066

this will build trust that the product is greener and company could differentiate themselves from other companies in the market. As we have discussed in our literature review, this type of companies can build knowledge in the consumer about the environmental effects. On the basis of survey conducted by authors, choice of consumer decision about Energy Company and strategic question; the trend shows that the companies should put more focus in the development of their marketing mix when companies enter into new or existing market. The price factor is most important in marketing mix however this factor could be changed if companies involves in the Social responsibility.

\subsection{Managerial Implication}

This strategic matrix could be very useful for the marketing managers to understand the nature of the product they are offering to the new ro existing market based on their company actual position is low/high green. This model also provides a pave way for the mangers to understand what segment of the market they want to target and wanted to establish the position of the brand. Putting more focus on the greenness of the product rather than brand attributes, firms may reap the economic and financial benefits of the market and can established a competitive position for the product. Environmentally friendly segment is growing and all business firms need to understand the market demand conditions to respond accordingly. Through using this matrix manager can classification the market and their product offerings. 


\section{References}

Barnard, J. (2010), Daily News, Greenpeace criticizes Facebook over coal power for data center. [available online] http://www.dailynews.com/technology/ci_14920976 (April23, 2011)

Bauer, D. (2010), Global Giving: why giving back makes good business sense, a closer Look at the Philosophy of Corporate Philanthropy Senior Giving Manager, Dell Corporation. [available online] http://content.dell.com/us/en/corp/d/corp-comm/cr-giving-philosophy.aspx(April 23, 2010)

Banerjee, S., B. (1999), "Corporate environmentalism and the greening of strategic marketing", in Charter, M., Polonsky, M. (Eds.),Greener Marketing - A Global Perspective on Greening Marketing Practice, Greenleaf Publishing, Sheffield,16-40.

Baumann, H., \& Rex, E, (2007), Beyond Ecolabell: what green marketing can learn from conventional marketing? Journal of Cleaner Production, 15(6), 567-576.

Benedetto, C., A. (1995), Behaviors of Environmentally Concerned Firms: An Agenda for Effective Strategic Development: In Polonsky Michael Jay, and Mintu-Wimsatt A.T (Eds.). Environmental Marketing. New York: Haworth Press.

Bird, L., Wüstenhagen, R., \& Aabakken, J. (2002), A review of international green power markets: recent experience, trends,and market drivers. Renewable and Sustainable Energy Reviews, 6(6), 513-536.

Charter, M., \& Polonsky, M., J. (1999), Green Power. In Wholgemuth, N., Getzner, M., \& Park, J. (Eds.), Green Marketing: A Global Prospective on Greening Marketing Practice (pp. 371-373).London: Greenleaf.

Chris, B., (2010), Dell Facebook Fans "Plant a Tree For a Friend"[available online ]http://en.community.dell.com/dellblogs/b/direct2dell/archive/2010/04/21/dell-facebo ok-fans-plant-a-tree-for-a-friend.aspx (April 24, 2011)

Darling, R., J. Heller, L. V., \& Tablada, M. D. (2009), Positioning a firm's initial market offering: a strategic application of a consumer-oriented model. European Business Review, 21(6), 516-530.

Davis, J., J. (1993), Strategies for environmental advertising. Journal of Consumer Marketing, 10(2), 19-36

Deeran, S.,(2010) [available online,] Archive for the green marketing Category. http://www.mygreenelement.com/category/green-marketing/(April 23, 2011)

Diamantopoulos, A., Schlegelmilch, B., B. Sinkovics, R., R. and Bohlen, G., M.(2003), Can socio-demographics still play a role in profiling green consumers? A review of the evidence and an empirical investigation, Journal of Business Research, 56 (6), 465-480.

D’Souza, C., and Taghian, M.(2010),Integrating Precautionary Principle approach in sustainable development decision making process: A proposal for a conceptual Framework, 
journal of macromarketing,30(2), 192-199

Ecolabelling green consumerism, (2011), [August 06, 2011] http://www.naturskyddsforeningen.se/in-english/Ecolabelling/(Aug 28, 2011)

Ek, Kristina., and So“ derholm, P.(2008), Households’ switching behavior between electricity suppliers in Sweden, Utility Policy, 16, 257-261

Environmental defense fund (2006), Starbucks Paper Project Changing the way coffee is served. [available online] http://www.edf.org/article.cfm?contentID=791 (April 22, 2010 from)

Environmentalleader, (2010), P\&G Expands 'Future Friendly' Marketing Effort.[March 15,2010]http://www.environmentalleader.com/2010/03/15/pg-expands-future-friendly-marke ting-effort/(April 24, 2010)

European Commission, (2010), Sustainable and responsible business: Corporate Social Responsibility

(CSR)fromhttp://ec.europa.eu/enterprise/policies/sustainable-business/corporate-social-respo nsibility/index_en.htm (April 10, 2010)

European Commission, (2010), [available online] http://ec.europa.eu/environment/ecolabel/about_ecolabel/facts_and_figures_en.htm (April 5, 2011)

Fuller, D., A. (1999), Sustainable Marketing: Managerial-Ecological Issues. Markets and Market Development. Sage Publications, California, USA. Grant, J. (2007), The Green Marketing Manifesto, John Wiley \& Sons Ltd, England.

Glaser, P., S. (2009), Green Power Marketing Claims: A Free Ride on Conventional Power?, Electricity Journal, 12(6), Pages 32-40.

Grankvist, G., Dahlstrand, U., and A. Biel, (2004) The impact of environmental labelling on consumer preference: negative vs. positive labels, Journal of Consumer Policy 27 (2), 213-230.

Greenpeace International Organization,(2011), Facebook update: Switch to renewable energy now,[Feb 19, 2010]

http://www.greenpeace.org/international/en/news/features/facebook-dump-coal190210/ (28 Aug,2011)

Green Starbucks, Eco-Friendly Cups Use No Plastic.[ September 16, 2007]http://greenstarbucks.wordpress.com/2007/09/16/eco-friendly-cups-uses-no-plastic/ (May 7,2011)

Håkansson, H., \& Waluszewsk, A. (2005), Developing a new understanding of markets: reinterpreting the 4Ps, Journal of Business \& Industrial Marketing, 20(3), 110-117.

Hanson, C. (2003), Corporate guide to green power markets: The Business Case for using 
renewable energy, corporate guide to green power. Retrieved on April 23, 2010 from http://thegreenpowergroup.org/pdf/Installment7.pdf

Hold, A., E. (1997), Disclosure and Certification: Truth and Labeling for Electric Power Renewable Energy Policy Project, No. 5, 1-18.

IKEA Foundation, SUNNAN - IKEA and UNICEF help enlighten children [available online] http://www.ikea.com/ms/en_US/about_ikea/our_responsibility/ikea_social_initiative/index.h tml (May 10,2011)

Kaberger, T. (2003), Environmental labeling of electricity delivery contracts in Sweden. Energy Policy. 31(7), 633-640.

Karna, J., Hansen. E., \& Juslin, H. (2003), Social responsibility in environmental marketing planning. European Journal of Marketing, 37 (5/6), 848-871.

Kotler, P. (2000), Marketing Management: The Millennium Edition, Prentice-Hall, Englewood Cliffs, NJ.

Kreidler, N., B. \& Joseph. M., S. (2009), How green should you go? Understanding the role of green atmospherics in service environment evaluations. International Journal of Culture, Tourism and Hospitality Research, 3(3), 228-245.

LaMonic, M. (2008), Google files patent for wave-powered floating data center. [available online]http://news.cnet.com/8301-11128_3-10034753-54.html?tag=mncol;title (June 27,2011)

Luukkanen, J. (2003), Green paper with green electricity? Greening strategies of Nordic pulp and paper industry, Energy Policy, 3(7), 641-655.

McDaniel, W. S., \& Rylander, H,.D.(1993), Strategic Green Marketing. Journal of Consumer Marketing, 10(3), 4-10.

Maignan, I., \& Ferrel, O,. C. (2004). Corporate Social Responsibility and Marketing: An Integrative Framework. Journal of the Academy of Marketing Science. (32)3. DOI: 10.1177/0092070303258971.

Miles, M.P. and Covin, J.G. (2000), "Environmental marketing: a source of reputational, competitive, and financial advantage”, Journal of Business Ethics, 23 (3). 299-311.

Ottman, J. A. (1993).Green Marketing: Challenges \& Opportunities for the New Marketing Age. Chicago. NTC Publishing Group. Book was issued from Malardalen University Library.

Ottman, J. A., Stafford, E,. R.. \& Hartman, C. L., (2006), Avoiding Green Marketing Myopia. Issue of Environment, 48(5) 22-36. Heldref Publications, 2006.

Peattie, K. (1995), Environmental Marketing Management - Meeting the Green Challenge, Pitman Publishing, London

Peattie, k. (2001),Golden goose or wild goose? The hunt for the green consumer, Business 
Strategy and the Environment, 10,187-199.

Peattie, K.,\& Crane. A.(2005),Green Marketing: Legend, myth, farce or prophesy?.Qualitative Market Research, 8(4). 357-370.

Peattie, k. (2005), Green marketing: legend, myth, farce or prophesy?. Qualitative Market Research, 8(4), 357-370.

Polonsky, J., M. Alma, T., M. \& Mintu, W. (1995), Environmental Marketing: Strategies, Practices, Theory, and Research. Newyork: The Haworth Press, Inc.

Porter, M.E., van der Linde, C. (1995), Green and competitive: ending the stalemate, Harvard Business Review, Vol. 73 No.5, 120-34.

Robins, F. (2008), why corporate social responsibility should be popularized but not imposed. Corporate Governance. 8(3), 330-341

Sheth, J., Parvatiyar, A. (1995), "Ecological imperatives and the role of marketing", in Polonsky, M.,Mintu-Wimsatt,A.(Eds.),Environmental Marketing: Strategies, Practice, Theory and Research, The Haworth Press, New York, NY, p.3-20.

Shi, W. (2010), Renewable energy: Finding solutions for a greener tomarrow. Reviews in Environmental Science and Biotechnology, 9(1), 35-37.

Sirsly, C., T. \& Lametrz, K. (2008), When Does a Corporate Social Responsibility Initiative Provide a First-Mover Advantage? Business \& Society, 47(3), 343-369.

Simula, H., Lehtimark, T., \& Salo, J. (2009), Managing Greenness, Journal of systems and Information Technology, 11(4), 331-346.

Straughan, D.,R. and Roberts,A.,J.(1999), Environmental segmentation alternatives,(1999), a look at green consumer behavior in the new millennium, Journal of Consumer Marketing 16 (6), 558-575.

Swedish Institute, (2011), Energy: Generating power for a sustainable future. [online available] http://www.sweden.se/eng/Home/Society/Sustainability/Facts/Energy/ (28 Aug, 2011)

Thøgersen, J. (2000), Psychological determinants of paying attention of eco-labels in purchase decisions: model development and multinational validation, Journal of Consumer Policy 23 285-313

Vaccaro, L., V. (2009), B2B Green Marketing and Innovation theory for competitive advantage. Journal of systems and Information Technology, 11(4), 315-330.

Volvocars, (2011), Volvo’s car approach towards sustainability.[Online Availble] http://www.volvocars.com/intl/top/about/corporate/volvo-sustainability/a-sustainable-approa ch-to-business/pages/default.aspx (28 Aug.2011)

Wal-Mart globally social responsibility report, (2011),[available online] http://walmartstores.com/sites/ResponsibilityReport/2011/environment_products_ImprovedP 
roducts.aspx(24 aug, 2011)

Wang, Y. (2006), Renewable electricity in Sweden: an Analysis of policy and regulations, Energy Policy,34, 1209-1220.

Wiser, R., H (1998), Green power marketing: increasing customer demand for renewable energy, Utilities Policy, 7(2), 107-119.

Wehrmeyer, M. (1999), "Reviewing corporate environmental strategy", in Charter, M. , Polonsky, M. (Eds),Greener Marketing - A Global Perspective on Greening Marketing Practice, Greenleaf Publishing, Sheffield, 41-56.

Wüstenhagen, R (Network Wüstenhagen: Pricing Strategies Conference 1998), Pricing Strategies on the Way to Ecological Mass Markets. [available online] http://www.greenhydro.ch/veroeffentlichungen/rom_wuestenhagen.pdf ( Feb 14,2011)

\section{Abbreviations}

SSNC

CNN's

CSR

IKEA

TERI
Swedish Society for Nature Conservation

Cable News Networks

Corporate Social Responsibility

Ingvar Kamprad Elmtaryd Agunnaryd

The Energy and Resource Institute 